\title{
EKSEKUSI HAK TANGGUNGAN SEBAGAI ALTERNATIF PENYELESAIAN KREDIT MACET (Studi di Bank ARTA ANUGRAH Lamongan)
}

\author{
Dhevy Nayasari Sastradinata ${ }^{1}$ \\ ${ }^{1)}$ Dosen Fakultas Hukum Universitas Islam Lamongan
}

\begin{abstract}
ABSTRAK
Salah satu tujuan pembangunan nasional adalah terciptanya masyarakat adil makmur berdasarkan Pancasila dan UUD 1945. Guna mewujudkan keadilan yang merata, maka peraturan perundangan Salah satu tujuan pembangunan yang telah sah diberlakukan harus dijunjung tinggi oleh segenap lapisan masyarakat. Salah satunya adalah Undang-undang No. 4 Tahun 1996 tentang Hak Tanggungan, yang mengatur tentang perjanjian antara pihak piutang dan berhutang. Sebagaimana telah diketahui, kredit macet merupakan persoalan serius yang dihadapi industri perbankan di Indonesia. Bank Arta Anugrah Lamongan sebagai salah satu lembaga keuangan yang bergerak dibidang simpan pinjam juga tidak bisa lepas dari persoalan kredit macet. Meskipun pihak Bank Arta Anugrah sebelum mengabulkan permohonan kredit telah melakukan analisis usaha nasabah, namun wanprestasi tetap terjadi. Dalam KUH Perdata yang dikuatkan dengan Undang-undang No. 4 Tahun 1996 tentang Hak Tanggungan, pihak kreditur sebetulnya bisa langsung melakukan penyitaan sekaligus eksekusi dan prakteknya, pelaksanaan eksekusi berdasar UUHT masih menemui beberapa kendala, karena itu pihak Bank Arta Anugrah lebih mengutamakan jalan persuasif dalam menyelesaikan kredit macet. Pelaksanaan eksekusi barang jaminan dengan cara melelang barang jaminan berdasar UUHT hanya merupakan alternatif saja apabila pendekatan persuasif dengan nasabah gagal menyelesaikan masalah. Mengingat UUHT yang bertujuan melindungi pihak kreditur masih banyak menuai kendala apabila diterapkan pada debitur wanprestasi, maka sebaiknya pihak Bank Arta Anugrah harua lebih selektif dalam menyalurkan kredit kepada nasabah.
\end{abstract}

\section{Kata kunci : Eksekusi hak tanggungan, Kredit Macet}

1. PENDAHULUAN

1.1 Latar Belakang

Tujuan pembangunan nasional

secara umum adalah meningkatkan

taraf hidup masyarakat secara

keseluruhan. Pembangunan harus dilaksanakan secara serentak berdasarkan pada UUD 1945. Untuk melaksanakan pembangunan tersebut diperlukan sumber pendanaan baik yang berasal dari APBN, hutang luar negeri, dan lain-lain. Dalam 
pelaksanaan pembangunan nasional tersebut diperlukan partisipasi aktif masyarakat agar tujuan pembangunan bisa terlaksana. Salah satu elemen yang berperan penting dalam menyukseskan pembangunan adalah lembaga keuangan, karena lembaga keuangan merupakan lembaga yang mampu melakukan intermediasi antara pihak yang kelebihan dana dan pihak yang memerlukan pendanaan.

Lembaga keuangan membuka kesempatan yang luas kepada masyarakat dan memberi kepercayaan penuh untuk mengalokasikan dana yang tersedia. Dana yang terhimpun dari masyarakat akan disalurkan dengan cara memberikan kredit bagi perorangan, pengusaha kecil, pengusaha menengah ataupun koperasi dalam rangka memeratakan usaha dan memperluas lapangan kerja. Peran strategis tersebut terutama disebabkan oleh fungsi utama bank sebagai suatu wahana yang dapat menghimpun dan menyalurkan dana masyarakat secara efektif dan efisien. Azaz demokrasi ekonomi dikonsepkan mendukung pelaksanaan pembangunan nasional demi terwujudnya pemerataan pembengunan nasional dan hasilhasilnya, pertumbuhan ekonomi dan stabilitas kearah taraf hidup rakyat.

$$
\text { Masalah kredit macet }
$$
merupakan penyakit kronis yang melanda kondisi perbankan di Indonesia. Data dari Bank Indonesia memperlihatkan bahwa jumlah kredit yang disalurkan oleh seluruh Bank Indonesia hingga triwulan III-2012 mencapai 2.511 triliun.[1]

Salah satu lembaga keuangan yang berkecimpung dalam masalah pendanaan dan penyaluran kredit adalah Bank Arta Anugrah Lamongan. Sebagaimana lembaga keuangan lain,
Bank Arta Anugrah Lamongan juga diharapkan pada masalah klasik yaitu adanya kredit macet yang mempunyai beberapa cara diantaranya dengan penjualan dibawah tangan terhadap jaminan kredit, keringanan hutang maupun ekskusi dengan cara melelang barang jaminan.

Salah satu upaya Bank Arta Anugrah Lamongan dalam menyelesaikan hutang macet agar piutangnya bisa tertagih adalah dengan cara melaksanakan ekskusi Hak Tanggungan. Ekskusi Hak tanggungan berupa pelejangan barang jaminan milik debitur biasanya dilakukan sebagai upaya terakhir apabila cara persuasif tidak bisa diselesaikan. Pengertian Ekskusi berdasar UndangUndang No. 4 tahun 1996 tentang Hak Tanggungan dalam pasal 20 adalah bahwa apabila debitor cidera janji, Objek Hak Tanggungan (HT) oleh kreditor pemegang HT dijual melalui pelelangan umum menurut cara yang ditentukan dalam peraturan perundang-undangan yang berlaku dan kreditor pemegang HT berhak mengambil seluruh atau sebagian dari hasil-hasilnya untuk pelunasan piutangnya yang dijamin dengan HT tersebut, dengan hak mendahulu dari pada kreditor-kreditor yang lain.[2] Keistimewaan dari HT adalah mudah dan pasti pelaksanaan eksekusinya. Apabila debitor cidera janji tidak perlu ditempuh acara gugatan perdata biasa, yang memakan biaya. Alternatif penyelesaian kredit macet yang dilakukan oleh Bank Arta Anugrah Lamongan agar kewajiban debitur bisa terpenuhi adalah dengan cara melakukan lelang ekskusi hak tanggungan melalui instrument perundangan sebagaimana diatur 
dalam Undang-undang No. 4 tahun 1996 tentang Hak Tanggungan.

\subsection{Rumusan Masalah}

Berdasarkan latar belakang tersebut diatas maka penulis mengetengahkan dua permasalahan yaitu:

1. Bagaimana pelaksanaan eksekusi hak tanggungan menurut UndangUndang No.4 Tahun 1996 tentang Hak Tanggungan?

2. Bagaimana kekuatan hukum eksekutorial dalam mengeksekusi barang jaminan milik debitur ?

\subsection{Tujuan Penelitian}

Ada beberapa tujuan yang hendak dicapai dalam penulisan ini :

1. Untuk mengkaji eksekusi hak tanggungan sebagai alternatif penyelesaian kredit macet di menurut Undang-Undang No.4 Tahun 1996 tentang Hak Tanggungan.

2. Untuk mengetahui kekuatan hukum eksekutorial dalam mengeksekusi barang jaminan milik debitur.

\section{METODE PENELITIAN}

Tipe penelitian hukum yang digunakan adalah yuridis normatif. Metode penelitian yuridis normatif adalah suatu prosedur penelitian ilmiah untuk menemukan kebenaran berdasarkan logika keilmuan dari sisi normatifnya.[3] Oleh karena tipe penelitian yang digunakan adalah tipe penelitian yuridis normatif, maka pendekatan yang digunakan adalah pendekatan perundang-undangan (Statuory Approach). Dalam metode pendekatan perundang-undangan peneliti perlu memahami hierarkhi dan asas-asas dalam peraturan perundangundangan.[4] Penulis menggunakan metode pendekatan secara yuridis normatif khususnya dalam pendekatan Perundang-undangan (Statuory Approach) yang nantinya akan dikaitkan dengan Undang-undang No.4 Tahun 1996 tentang Hak Tanggungan dan hukum positif di Indonesia. Di samping itu penulis memakai pendekatan kasus-kasus yang terjadi di Bank Arta Anugrah

Lamongan akibat wansprestasi dalam perjanjian tersebut.

\section{HASIL DAN PEMBAHASAN}

Perjanjian merupakan sumber penting yang melahirkan perikatan. Memang, perikatan itu paling banyak diterbitkan oleh suatu perjanjian, tetapi sebagaimana sudah sebutkan. ada juga sumber-sumber lain yang melahirkan perikatan. Sumber-sumber lain ini tercakup dengan nama undang-undang. Jadi perikatan yang lahir dari perjanjian dan ada perikatan yang lahir dari undang-undang. Suatu perjanjian agar sah menurut hukum maka harus memenuhi syarat-syarat yang telah ditetapkan oleh undang-undang, yaitu diatur dalam Pasal 1320 KUH Perdata. Pengertian kredit yaitu penyediaan uang atau tagihan yang dapat dipersamakan dengan itu. Berdasarkan persetujuan atau kesepakatan pinjam meminjam antara bank dengan pihak lain yang mewajiban pihak peminjam untuk melunasi hutangnya sebuah jangka waktu tertentu dengan jumlah bunga imbalan dan kata kredit itu sendiri berasal dari bahasa Romawi yaitu credere, artinya percaya dan dalam bahasa Inggris belive. Perjanjian kredit merupakan perikatan yang 
termasuk dalam perjanjian pinjam meminjam sesuai Pasal 1754 KUH Perdata. Sedangakan menurut Pasal 1 ayat (11) Undang-undang Nomor 10 Tahun 1998 tentang perbankan, yang dimaksud dengan perjanjian kredit adalah penyediaan uang atau tagihan yang dapat dipersamakan dengan itu berdasarkan persetujuan atau kesepakatan pinjam meminjam antara Bank dengan pihak lain yang mewajiban pihak peminjam untuk melunasi hutangnya setelah jangka waktu tertentu dengan pemberian bunga. Berdasarkan Surat Edaran Bank Indonesia Nomor 26/4/BPP tanggal 29 Mei. 1993 dikatakan bahwa kredit digolongkan macet apabila:

1. Tidak memenuhi kriteria lancar, kurang lancar dan diragukan seperti tersebut pada angka 4.1, 4.2, dan 4.3 atau;

2. Memenuhi kriteria diragukan tersebut pada angka 4.3 tetapi dalam jangka waktu 21 bulan sejak digolongkan diragukan belum ada pelunasan atau usaha penyelamatan kredit; atau

3. Kredit tersebut penyelesaiannya telah diserahkan kepada Pengadilan Negeri atau Badan Urusan Piutang Negara (BUPN) atau telah diajukan penggantian ganti rugi kepada perusahaan asuransi kredit.

Alternative lain dalam penyelesaian kredit macet yaitu litigasi dan non litigasi. Litigasi adalah dengan mendayagunakan lembaga peradilan yang ada, baik pengadilan negeri, pengadilan niaga, ataupun panitia urusan piutang negara (PUPN) bagi bank-bank milik pemerintah. Non litigasi memiliki pengertian yang sama dengan ADR (Alternatif Dispute Resolution) yaitu penyelesaian sengketa diluar pengadilan yang dilakukan secara damai. ADR meliputi negosiasi dan mediasi. Negosiasi adalah sebagai interaksi, dimana dua orang atau lebih terlibat secara bersama dimana awalnya mereka memiliki sasaran yang berbeda dengan menggunakan argumen dan persuasi mencoba untuk menyudahi perbedaan tersebut. Penyelesaian dengan cara negosiasi tidak melibatkan pihak ketiga jadi hanya antara yang bersengketa (debitur dan kreditur). Menurut Bank Indonesia Mediasi adalah alternatif penyelesaian sengketa perbankan yang bermanfaat bagi perlindungan nasabah dan dalam upaya menjaga terpeliharanya reputasi bank. Pengertian eksekusi yang menyangkut dalam pembangunan sejumlah uang adalah dengan menyita dan melelang barang-barang pihak yang di kalahkan.[5] Menurut Pasal 1 ayat 1 Undang-Undang No. 4 Tahun 1996 tentang Hak Tangungan bahwasannya Hak Tanggungan adalah hak jaminan yang dibebankan pada hak atas tanah sebagaimana dimaksud dalam Undang-Undang No. 5 Tahun 1960 tentang peraturan dasar pokokpokok agraria, berikut atau tidak berikut benda-benda lain yang merupakan suatu kesatuan dengan tanah itu. Untuk pelunasan utang tertentu yang memberikan kedudukan yang diutamakan kepada kreditur terhadap kreditur-kreditur lain. Hak tanggungan mempunyai sifat tidak dapat dibagi-bagi kecuali jika diperijinkan dalam akta pemberian hak tanggungan. Untuk mengatasi kredit macet, Bank Arta Anugrah melakukan langkah pengamanan untuk menghindari kerugian yang makin menderita, prosedur penyelesaiannya antara lain : 
1. Untuk peminjam lancar, diadakan penyelesaian atau penagihan bunga serta ongkos-ongkos yang timbul kepada debitur yang bersangkutan.

2. Menerima pelunasan baik secara tunai maupun disertai pengembalian atas barang jaminan.

3. Untuk peminjam yang telah jatuh tempo secepatnya diadakan perpanjangan kreditnya kembali agar supaya tidak terjadi kredit macet.

4. Apabila setelah perpanjangan waktu keadaan usaha debitur masih kurang baik maka diadakan usaha pembinaan serta saran-saran.

5. Sebagai langkah terakhir dalam penyelesaian pinjaman kredit macet adalah penagihannya, diserahkan kepada KPKNL untuk diadakan lelang ataupun penjualan dibawah tangan.

\section{PENUTUP}

\subsection{Kesimpulan}

Berdasarkan hasil penelitian dan pembahasan yang telah diuraikan diatas maka dapat ditarik kesimpulan sebagai berikut :

Untuk menyelesaikan kredit macet yang telah terjadi Bank Arta Anugrah melakukan pembinaan kepada nasabah berupa :

- Melakukan musyawarah antara nasabah atau debitur dan pihak Bank Arta Anugrah untuk mencari jalan yang terbaik untuk menyelesaikan hutang itu

- Mengirimka Surat Teguran kepada nasabah/debitur oleh petugas dimana dijelaskan resiko yang ditanggung kalau nanti berurusan dengan pengadilan.

Apabila hal tersebut tidak berhasil maka alternatif terakhir dilakukan oleh Bank Arta Anugrah dengan melakukan Lelang Eksekusi Hak Tanggungan barang jaminan melalui Kantor Pelayanan Kekayaan Negara dan Lelang (KPKNL). Hal ini sejalan dengan ketentuan Pasal 1131 dan 1132 KUH Perdata yang dapat diinterprestasikan bahwa kekayaan seseorang dapat dijadikan jaminan untuk semua kewajiban atau utangnya, sehingga kreditur dapat melaksanakan haknya terhadap semua benda debitur, kecuali benda-benda yang dikecualikan oleh Undang-undang. Dengan demikian kreditur dapat melakukan penyitaan dan pelelangan untuk melunasi hutang debitur.

\subsection{Saran}

1. Bank Arta Anugrah hendaknya meningkatkan sumber daya manusianya terutama mengenai operasional kredit, sebab kelangsungan daripada Bank Arta Anugrah sebagian besar tergantung dari kredit, sehingga dibutuhkan sumber daya manusia yang profesional untuk bisa menanganinya, terutama yang mempunyai visi dan intelektual yang baik.

2. Untuk mengurangi terjadinya wanprestasi dari pihak nasabah, hendaknya petugas Bank Arta Anugrah harus lebih selektif dan memilih nasabah yaiu dengan mengadakan penilaian terhadap usaha nasabah, kemampuan dan kesanggupannya dalam memenuhi kewajibannya. Juga penilaian terhadap karakter atau sikap nasabah yang bersangkutan.

3. Penyelesaian wanprestasi melalui penghapusan hutang mempunyai resiko yang besar apabila diketahui 
nasabah, karena hal tersebut akan dapat dijadikan alasan bagi nasabah untuk melakukan wanprestari. Selain itu apabila kurang pengawasan akan mudah dijadikan lahan manipulasi oleh petugas Bank Arta Anugrah. Oleh karena itu, sebaiknya penghapusan hutang ini ditiadakan dan terhadap nasabah yang melakukan wanprestasi tetap diadakan pembinaan, dan pendekatan agar mereka membayar hutangnya.

4. Untuk mencegah kemungkinan penyalahgunaan keuangan oleh petugas terhadap kredit yang telah disalurkan oleh Bank Arta Anugrah kepada nasabah, sebaiknya pengawasan dan pembinaan lebih ditingkatkan, bahkan bila diperlukan Bank Arta Anugrah dapat memberikan alternatif usaha lain, jika usaha yang dilakukan nasabah dimungkinkan tidak berkembang sebagaimana yang diharapkan.

\section{Catatan kaki :}

[1]

Finance.detik.com/search/=krm.ht $\mathrm{ml}$

[2] Boedi Harsono, Hukum Agraria Indonesia (Jakarta, Penerbit Jembatan), 2004, hal.457.

[3] Johnny Ibrahim, Teori dan Metodologi Penelitian Hukum Normatif, Banyu media publising, 2012, hal.57

[4] Peter Mahmud Marzuki, Penelitian Hukum, Penerbit Kencana Prenada Media Group, 2011, hal.96

[5] Sri Soedewi Masjchoen Sofwan, Hukum Jaminan di Indonesia Pokok-pokok Hukum Jaminan dan Jaminan Perorangan, hal.31

\section{DAFTAR PUSTAKA}

\section{Literatur :}

Boedi Harsono. Hukum Agraria Indonesia. Djambatan, Jakarta, 2003

Peter Mahmud Marzuki. Penelitian Hukum. Persada Media, Jakarta, 2005.

Sri Soedewi Masjchoen Sofwan, Hukum Jaminan di Indonesia Pokok-pokok Hukum Jaminan dan Jaminan Perorangan

Suharsimi Arikunto, Prosedur Penelitian, Rineka Cipta, Jakarta, 2002.

Johnny Ibrahim, Teori dan Metodologi Penelitian Hukum Normatif, Banyumedia Publising, Malang, 2012. 